\title{
EVALUATION OF THE BIOLOGICAL PARMATERS OF THE GREEN LACEWING, Chrysoperla carnea (NEUROPTERA: CHRYSOPIDAE) FED ON TWO APHID SPECIES AT TWO DIFFERENT TEMPERATURES \\ Al-Keherb, Wafa, A. \\ Collage of Science and Arts, Qassim University, Buraydah
}

\begin{abstract}
Laboratory studies were conducted to evaluate the role of two aphid species (Aphis craccivora Koch and Myzus persicae Sultzer) and two temperature degrees on certain biological aspects of the green lacewing aphid Chrysoperla carnea (Neuroptera: Chrysopidae). In order to evaluate its potential as biological control agent, some biological parameters and its consumption capacity were studied on the two aphid preys under laboratory conditions. The biological parameters were the same when the predator fed on $M$. persicae and $A$. craccivora. There are no significant differences were observed in the biological parameters when $C$. Carnea was fed on the two tested aphid preys. The average aphid consumption of $C$. carnea larvae to complete its development was $537.23,570.08$ of $A$. craccivora while it was 507.73 and 519.42 of $M$. Persicae at 25 and $30 \mathrm{oC}$, respectively. Therefore, the larvae of $C$. carnea can be regarded as a biological control agent for controlling aphid species.

Keywords: Green lacewing aphid, Chrysoperla carnea, Biological control, Aphis craccivora, Myzus persicae.
\end{abstract}

\section{INTRODUCTION}

Chemical control generally provides only short-term solutions. Moreover, the overuse of pesticides, in controlling the destructive pests, has developed a resistance to many insecticides (Damásio, et al. 2007). Additionally, residues of pesticides in the environment and impact on the human health safety are also a concern, supported by consumers demand of pesticide-free food. Thus, many countries are trying to reduce their use of chemical pesticides by developing an alternative safety control methods(Carvalho, 2006). Currently, the increasing demand on augmentative releases of certain insect natural enemies to eliminate the most destructive pests, among biological control programs, constitutes a worthy priority (Tauber et al., 2000). Among predatory insects, the green lacewing Chrysoperla carnea (Stephen) (Neuroptera: Chrysopidae) which can be considered one of the most polyphagous predators in biological control programs. (Sattar et al., 2007; Zia et al., 2008). Larvae of C. carnea are generalist predators that seem to reach higher larval performance when fed on some aphid species, in spite of their feeding on whiteflies, thrips, lepidopterous eggs and larvae, psyllids, mites and mealybugs (Legaspi et al., 1994; Syed et al., 2005; Sattar et al., 2007). Due to their high larval voracity (Principi and Canard, 1984), as well as, their relative tolerance to many insecticides (Nasreen et al., 2003; Zia et al.,2008), C. carnea, is potentially considered useful biological control agent of aphids and other soft-bodied 


\section{Al-Keherb, Wafa, A.}

insects (Legaspi et al., 1994; Daane, 2001; Mari et al., 2007). The predator larval stages have got a considerable attention, because of having higher searching ability and wide adaptability in greenhouses and fields than other predators (Miller et al., 2004). Certain Chrysopidae insect species mainly of the genus Chrysoperla have been successfully mass-reared and used in biological control programs either in greenhouses or in field (New, 1984). The biological control by using $C$. carnea has gained importance in IPM programs and paid attention of the entomologists around the world (Mochizuki and Mitsunaga, 2004; Corrales and Campos, 2004). Since, C. carnea is a widely distributed and abundant species world-wide, its important to determine the potential for generalist predators to suppress aphid species in agroecosystems, and the effect of host prey on its biological parameters.

\section{MATERIALS AND METHODS}

\section{Stock colony of Chrysoperla carnea:}

A stock colony of $C$. carnea was established with adults collected with a sweeping net from vegetable fields. Adults were maintained in cylindrical plastic cages $(20 \times 15 \mathrm{~cm})$ and provided with water, sugar and honey. Larvae were reared in glass Petri-dishes $(15 \mathrm{~cm}$ diameter) with plenty of Aphis gossypii (Glover) nymphs and adults offered daily as prey. The stock colony was maintained at $25 \pm 1^{\circ} \mathrm{C}$ and a photoperiod of 16:8 LD.

\section{Prey species}

Duration of different developmental larval stages, survival, adult longevity and fecundity of $C$. carnea were determined when larvae preyed upon two aphid species; the cowpea aphid, Aphis craccivora (Koch) and the green peach aphid, Myzus persicae (Sulzer) (Homoptera: aphididae) at two temperatures 25 and $30 \mathrm{oC}$. Prey nymphs and adults of $A$. craccivora and $M$. persicae were obtained from laboratory colonies maintained in an insectary on potted broad bean (Phaseolus vulgaris L.) and eggplants (Solanum melongena L.), respectively.

3. Effect of prey species on predator immature development and survival

In this experiment, 200 individuals of each aphid species were offered daily to each chrysopid larva throughout its larval development. Considering the non-prey species, every $24 \mathrm{~h}$ larval developmental stage and survival were recorded. All the experiments were carried out at $25 \pm 1,30 \pm 1{ }^{\circ} \mathrm{C}$ and a photoperiod of 16:8 LD. For each treatment (aphid species as a tested prey), 50 replicates of newly hatched lacewing larvae were tested but only those that completed their development were included in data analysis. In further data analysis, each larva of $C$. Carnea was considered as one replicate.

\section{Effect of larval prey species on adult longevity and fecundity}

Females and males that fed throughout their larval development on the two aphid species were transferred in pairs on the day of emergence and maintained in cylindrical plastic cages where they had continuous access to water mixed with honey and yeast. The number of deposited eggs by each female as well as female survival were daily recorded. Males that died were 
replaced with young ones. Egg hatchability was also estimated. Once a week during the first thirty days of the oviposition period, 15 randomly chosen eggs laid by each female were collected and transferred individually in plastic Petri dishes. Subsequently, predator eggs were maintained under the same temperature and photoperiodic conditions with the parental females. Daily deposited eggs and number of newly hatched larvae were recorded. The percentages of egg hatching at each sampling date were estimated for eggs laid by all tested females.

\section{Data analysis}

Analysis of variance (ANOVA) was used to compare the effect of prey species on developmental time of $C$. carnea. Within each treatment the $t$-test was used to compare total developmental times of females and males. ANOVA test was also used to compare longevity and fecundity of females as well as egg hatchability in the different treatments. Means were compared using Student-Newman-Keuls test $(P=0.005)$ (Costat, 1990).

\section{RESULTS}

\section{1-A- Biological aspects of Chrysoperla carnea fed on the cowpea aphid, Aphis craccivora (Koch):}

Duration (in days) of developmental stages of $C$. carnea fed on $A$. craccivora is shown in Table (1). The average of the incubation period lasted $3.75 \pm 0.26$ and $3.75 \pm 0.15$ days at 25 and $30^{\circ} \mathrm{C}$, respectively.

Regarding the larval stages, the duration of the 1st instar larvae of $C$. carnea averaged $3.40 \pm 0.58$ at $25^{\circ} \mathrm{C}$ and $2.51 \pm 0.16$ days at $30^{\circ} \mathrm{C}$. At $25^{\circ} \mathrm{C}$, the 2nd and 3rd larval instars lasted $2.58 \pm 0.058$ and $3.65 \pm 0.15$ days, respectively (Table 1 ). Meanwhile, the same instars required $2.22 \pm 0.15$ days for the 2nd instars and $2.85 \pm 0.058$ days for 3 rd instars at $30^{\circ} \mathrm{C}$ (Table 1). Accordingly, the total larval stages period of $C$. carnea were $8.96 \pm 0.55$ at $25^{\circ} \mathrm{C}$ and $6.91 \pm 0.32$ days at $30^{\circ} \mathrm{C}$ when fed on $A$. craccivora, respectively.

Data in Table (1) also revealed that the pupal stage period averaged $7.16 \pm 0.15$ days at $25^{\circ} \mathrm{C}$, while it lasted $5.67 \pm 0.058$ days at $30^{\circ} \mathrm{C}$, respectively.

In respect of the adulthood of $C$. carnea adults, the pre-oviposition period required $6.45 \pm 0.15$ days at $25^{\circ} \mathrm{C}$, and $5.88 \pm 0.18$ days at $30^{\circ} \mathrm{C}$. Meanwhile, the oviposition and the post-oviposition periods lasted $25.58 \pm 1.85,6.97 \pm 0.18$ days at $25^{\circ} \mathrm{C}$, and $17.79 \pm 0.25,4.65 \pm 0.25$ days at $30^{\circ} \mathrm{C}$, respectively (Table 1 ).

Females fecundity was also affected by temperature when fed on $A$. craccivora. A female deposited an average of $168.45 \pm 4.52$ eggs at $25^{\circ} \mathrm{C}$, and $131.43 \pm 6.25$ eggs at $30^{\circ} \mathrm{C}$ respectively (Table 1 ).

Longevity of $C$. carnea female and male is represented in Figure (1). Female and male longevity lasted $37.33 \pm 1.57$ and $30.75 \pm 0.15$ days at $25^{\circ} \mathrm{C}$ and reached $26.67 \pm 1.53$ and $20.35 \pm 0.55$ days at $30^{\circ} \mathrm{C}$, respectively. Whereas, the adult's lifespan at $25^{\circ} \mathrm{C}$ was obviously longer than that at $30^{\circ} \mathrm{C}$, which recorded $38.67 \pm 0.58$ and $31.65 \pm 0.55$ days and $28.33 \pm 0.57$ and $21.56 \pm 0.83$ days at $25^{\circ} \mathrm{C}$ for female and male, respectively. 
Al-Keherb, Wafa, A.

Table (1): Duration of different stages of Chrysoperla carnea fed on the cowpea aphid, Aphis craccivora at two temperature regimes (25 and $30^{\circ} \mathrm{C}$ ).

\begin{tabular}{|l|c|c|}
\hline \multicolumn{1}{|c|}{ Developmental stages } & \multicolumn{2}{c|}{ Duration (in days) (Means \pm SE) } \\
\cline { 2 - 3 } & at $\mathbf{2 5 ^ { \circ } \mathbf { C }}$ & at $\mathbf{3 0} \mathbf{0}^{\circ} \mathbf{C}$ \\
\hline Incubation period & $3.75 \pm 0.26 \mathrm{a}$ & $3.75 \pm 0.15 \mathrm{a}$ \\
\hline 1st stage larva & $3.40 \pm 0.58 \mathrm{a}$ & $2.51 \pm 0.16 \mathrm{~b}$ \\
\hline 2nd stage larva & $2.58 \pm 0.058 \mathrm{a}$ & $2.22 \pm 0.15 \mathrm{a}$ \\
\hline 3rd stage larva & $3.65 \pm 0.15 \mathrm{a}$ & $2.85 \pm 0.058 \mathrm{~b}$ \\
\hline Total larval period & $8.96 \pm 0.55 \mathrm{a}$ & $6.91 \pm 0.32 \mathrm{~b}$ \\
\hline Pupal stage & $7.16 \pm 0.15 \mathrm{a}$ & $5.67 \pm 0.058 \mathrm{ab}$ \\
\hline Pre-oviposition period & $6.45 \pm 0.15 \mathrm{a}$ & $5.88 \pm 0.18 \mathrm{a}$ \\
\hline Oviposition period & $25.58 \pm 1.85 \mathrm{a}$ & $17.79 \pm 0.25 \mathrm{~b}$ \\
\hline Post-oviposition period & $6.97 \pm 0.18 \mathrm{a}$ & $4.65 \pm 0.25 \mathrm{~b}$ \\
\hline Total average of eggs/female (fecundity) & $168.45 \pm 4.52 \mathrm{a}$ & $131.43 \pm 6.25 \mathrm{~b}$ \\
\hline
\end{tabular}

a - means followed by the same letter within a same row are not significantly different at (0.05\%) (Duncan Multiple Rang test)

Figure (1): Longivety of females and males of Chrysoperla carnea fed on Aphis craccivora at two temperature regiems.

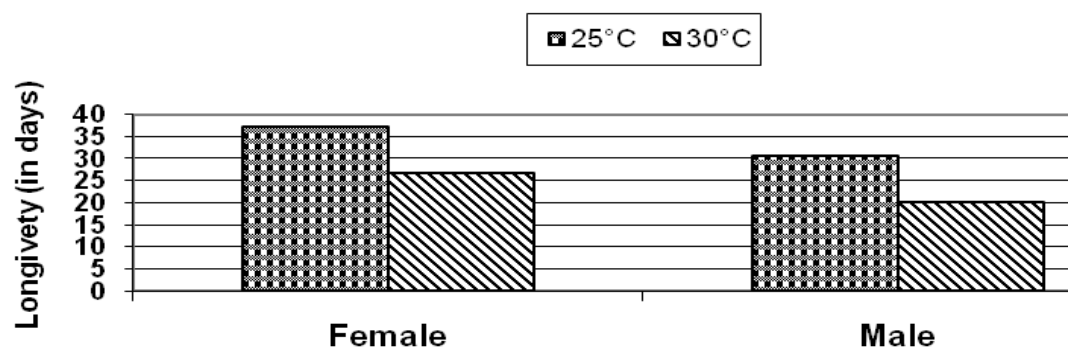

C. carnea

Figure (2): Life sapn of females and males of Chrysoperla carnea fed on Aphis craccivora at two temperature regiems.

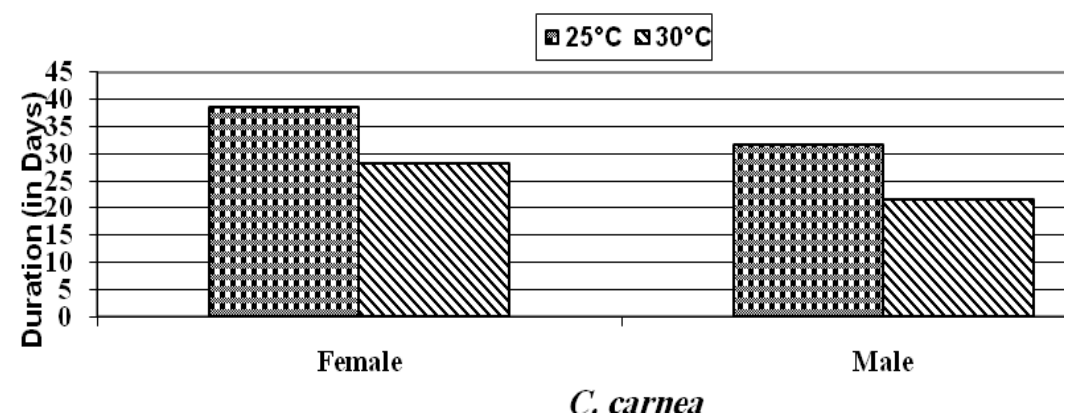


1-B- Consumption rates of Aphis craccivora by larval stages of $C$. carnea at 25 and $30^{\circ} \mathrm{C}$ :

Data in Table (2) revealed that the larval stages of $C$. carnea consumed nymphs of $A$. craccivora. The average number of consumed nymphs of $A$. craccivora by $C$. carnea 1 st, 2 nd and 3rd larval instars, at $25^{\circ} \mathrm{C}$ were $27.65 \pm 1.55,158.23 \pm 1.25$ and $351.35 \pm 0.58$ individuals, respectively with an average of $537.23 \pm 1.98$ individuals, while, they consumed $33.25 \pm 1.52$, $175.31 \pm 3.12$ and $361.52 \pm 2.15$ nymphs at $30^{\circ} \mathrm{C}$, respectively, with a total average of $570.08 \pm 3.54$ individuals. From the previous results it can be said that $C$. carnea can use nymphs of $A$. craccivora to complete its lifespan and that may be considered as potential biological control agent against different species of aphids.

Table (2): Consumed numbers of Aphis craccivora nymphs by different larval instars of Chrysoperla carnea at 25 and $30^{\circ} \mathrm{C}$.

\begin{tabular}{|c|c|c|}
\hline \multirow{2}{*}{ Stages } & \multicolumn{2}{|c|}{$\begin{array}{c}\text { No. of consumed } \mathbf{A} \text { craccivora nymphs/ larva of } \mathbf{C} \text {. carnea } \\
\text { (Means } \pm \text { SE) }\end{array}$} \\
\cline { 2 - 3 } & at $\mathbf{2 5}^{\circ} \mathbf{C}$ & at $\mathbf{3 0}^{\circ} \mathbf{C}$ \\
\hline 1st instar & $27.65 \pm 1.55 \mathrm{~b}$ & $33.25 \pm 1.52 \mathrm{a}$ \\
\hline 2nd instar & $158.23 \pm 1.25 \mathrm{ab}$ & $175.31 \pm 3.12 \mathrm{a}$ \\
\hline 3rd instar & $351.35 \pm 0.58 \mathrm{ab}$ & $361.52 \pm 2.15 \mathrm{a}$ \\
\hline Total average & $537.23 \pm 1.98 \mathrm{ab}$ & $570.08 \pm 3.54 \mathrm{a}$ \\
\hline
\end{tabular}

a - means followed by the same letter within a same row are not significantly different at (0.05\%) (Duncan Multiple Rang test)

\section{2-A- Biological aspects of Chrysoperla carnea fed on the green peach aphid, Myzus persicae (Sulzer);}

Duration (in days) of developmental stages of $C$. carnea fed on $M$. persicae is shown in Table (3). The incubation period lasted $3.25 \pm 0.15$ and $3.05 \pm 0.20$ days at 25 and $30^{\circ} \mathrm{C}$, respectively. Regarding larval stages, the duration of the 1 st instar larvae of $C$. carnea averaged $3.42 \pm 0.25$ at $25^{\circ} \mathrm{C}$ and $2.45 \pm 0.15$ days at $30^{\circ} \mathrm{C}$. Whereas, the 2 nd and 3rd larval instars lasted $2.55 \pm 0.15$ and $3.41 \pm 0.18$ days at $25^{\circ} \mathrm{C}$, respectively. Meanwhile, the same instars required $2.01 \pm 0.22$ and $2.56 \pm 0.15$ days at $30^{\circ} \mathrm{C}$, respectively (Table 3 ). Accordingly, the total larval stages of $C$. carnea durated $8.89 \pm 0.50$ at $25^{\circ} \mathrm{C}$ and $7.01 \pm 0.23$ days at $30^{\circ} \mathrm{C}$ when fed on M. persicae. The pupal stage period averaged $8.01 \pm 0.15$ days at $25^{\circ} \mathrm{C}$, while it lasted $5.87 \pm 0.15$ days at $30^{\circ} \mathrm{C}$, respectively as shown in Table (3).

In respect of the biological parameters of $C$. carnea adults, the preoviposition period required $6.88 \pm 0.18$ days at $25^{\circ} \mathrm{C}$, and $5.15 \pm 0.12$ days at $30^{\circ} \mathrm{C}$. Meanwhile, the oviposition and post-oviposition periods averaged $26.14 \pm 1.74,6.11 \pm 0.25$ days at $25^{\circ} \mathrm{C}$, and $17.10 \pm 0.15,4.44 \pm 0.18$ days at $30^{\circ} \mathrm{C}$ (Table 3).

Females fecundity was also affected by temperature when fed on $M$. persicae. A female laid an average of $164.31 \pm 4.28$ eggs at $25^{\circ} \mathrm{C}$, and $128.25 \pm 4.25$ eggs at $30^{\circ} \mathrm{C}$, respectively. 
Al-Keherb, Wafa, A.

Table (3): Duration of different stages of Chrysoperla carnea fed on Myzus persicae at two temperature regimes $\left(25\right.$ and $\left.30^{\circ} \mathrm{C}\right)$.

\begin{tabular}{|c|c|c|}
\hline \multirow{2}{*}{ Developmental stages } & \multicolumn{2}{|c|}{ Duration (in days) (Mean \pm SE) } \\
\hline & & \\
\hline Incubation period & $3.25 \pm 0.15 \mathrm{a}$ & $3.05 \pm 0.20 \mathrm{a}$ \\
\hline 1st stage larva & $3.42 \pm 0.25 \mathrm{a}$ & $2.45 \pm 0.15 \mathrm{~b}$ \\
\hline 2nd stage larva & $2.55 \pm 0.15 \mathrm{a}$ & $2.01 \pm 0.22 \mathrm{a}$ \\
\hline 3rd stage larva & $3.41 \pm 0.18 \mathrm{a}$ & $2.56 \pm 0.15 \mathrm{~b}$ \\
\hline Total larval period & $8.89 \pm 0.50 \mathrm{a}$ & $7.01 \pm 0.23 \mathrm{~b}$ \\
\hline Pupal stage & $8.01 \pm 0.15 \mathrm{a}$ & $5.87 \pm 0.15 b$ \\
\hline Pre-oviposition period & $6.88 \pm 0.18 \mathrm{a}$ & $5.15 \pm 0.12 b$ \\
\hline Oviposition period & $26.14 \pm 1.74 \mathrm{a}$ & $17.10 \pm 0.15 b$ \\
\hline Post-oviposition period & $6.11 \pm 0.25 \mathrm{a}$ & $4.44 \pm 0.18 \mathrm{~b}$ \\
\hline Total average of eggs/female (fecundity) & $164.31 \pm 4.28 \mathrm{a}$ & $128.25 \pm 4.25 \mathrm{~b}$ \\
\hline
\end{tabular}

Figure (3). Longevity of females and males of Chrysoperla carnea fed on Aphis craccivora at two temperature regiems.

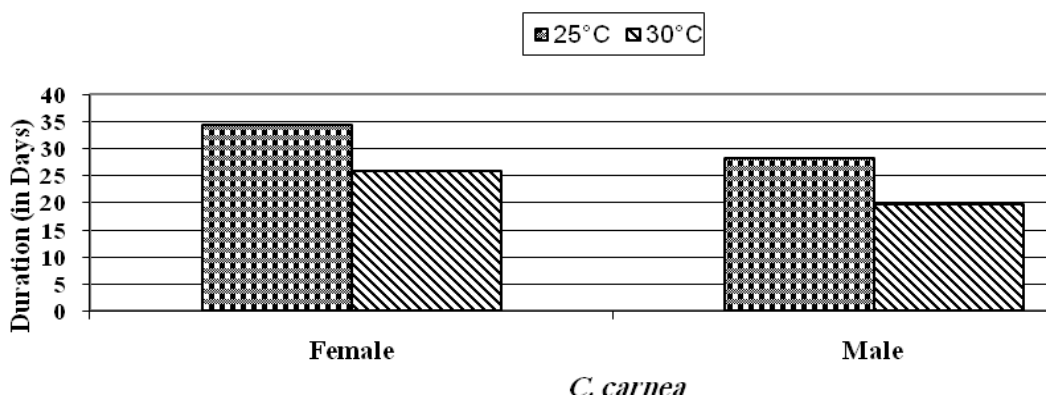

Figure (4): Life sapn of females and males of Chrysoperla carnea fed on Myzus persicae at two temperature regiems.

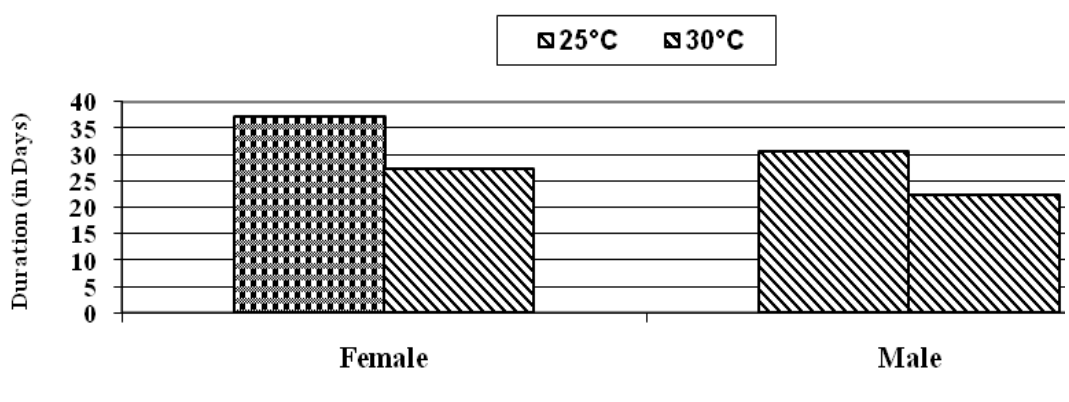

C. carnea 
Female and male longevity lasted $34.35 \pm 1.65$ and $28.25 \pm 0.25$ days at $25^{\circ} \mathrm{C}$ and reached $25.66 \pm 1.25$ and $19.55 \pm 0.55$ days at $30^{\circ} \mathrm{C}$ (Fig.3). The adult's lifespan at $25^{\circ} \mathrm{C}$ was longer than that at $30^{\circ} \mathrm{C}$, which lasted $37.25 \pm 0.56$ and $30.65 \pm 0.58$ days for female and male at $25^{\circ} \mathrm{C}$, and $27.25 \pm 1.25$ and $22.55 \pm 0.56$ days for female and male at $30^{\circ} \mathrm{C}$, respectively (Fig. 4).

2-B- Consumption rates of Myzus persicae by larval stages of $C$. carnea at 25 and $30^{\circ} \mathrm{C}$ :

Data in Table (4) revealed that the larval stages of $C$. carnea consumed nymphs of $A$. craccivora. The average number of consumed nymphs of $A$. craccivora by $C$. carnea 1 st, 2 nd and 3rd larval instars were $24.85 \pm 1.22,147.21 \pm 1.55$ and $335.67 \pm 0.15$ individuals at $25^{\circ} \mathrm{C}$, respectively. While they consumed $30.96 \pm 1.58,166.35 \pm 2.15$ and $352.11 \pm 2.18$ eggs at $30^{\circ} \mathrm{C}$, respectively.

From the previous results it can be noticed that $C$. carnea used nymphs of $A$. craccivora to complete its lifespan and may be therefore considered as a potential biological control agent against different species of aphids.

Table (4): Consumed numbers of Myzus persicae nymphs by different larval instars of Chrysoperla carnea at 25 and $30^{\circ} \mathrm{C}$.

\begin{tabular}{|c|c|c|}
\hline \multirow{2}{*}{ Stages } & $\begin{array}{c}\text { Consumed numbers of } \boldsymbol{M} \text {. persicae nymphs/ larva of } \mathbf{C} . \\
\text { carnea (Means } \pm \text { SE) }\end{array}$ \\
\cline { 2 - 3 } & ${\text { at } \mathbf{2 5} \mathbf{5}^{\circ} \mathbf{C}}^{\text {at } \mathbf{3 0}} \mathbf{C}$ \\
\hline 1st instar & $24.85 \pm 1.22 \mathrm{~b}$ & $30.96 \pm 1.58 \mathrm{a}$ \\
\hline 2nd instar & $147.21 \pm 1.55 \mathrm{~b}$ & $166.35 \pm 2.15 \mathrm{a}$ \\
\hline 3rd instar & $335.67 \pm 0.15 \mathrm{ab}$ & $352.11 \pm 2.18 \mathrm{a}$ \\
\hline Average (total) & $507.73 \pm 3.78 \mathrm{a}$ & $519.42 \pm 3.62 \mathrm{a}$ \\
\hline
\end{tabular}

a - means followed by the same letter within a same row are not significantly different at (0.05\%) (Duncan Multiple Rang test)

\section{Effect of aphid species on the biological parameters of Chrysoperla} carnea:

From the above mentioned results it could be concluded that both aphid species had an impact on the biological features of the predator (Tables $1 \& 3$ ). Both aphid species were equal in their effectiveness on the predator biological parameters, where no significant differences were observed when the predator fed on the two aphid species. In respect of the consumption numbers of the two aphid species, it could be noticed that $A$. craccivora was the preferred prey species. The predator larvae consumed an average of 537.23 and 570.52 individuals of $A$. craccivora and 507.73 and 519.42 of $M$. persicae at 25 and $30 \mathrm{oC}$, respectively.

\section{DISCUSSION}

Chrysoperla carnea larvae can prey on a variety of soft-bodied arthropods like aphids, coccids, leafhoppers, whiteflies, psyllids, thrips, psocids, tetranychid and eriophyid mites, eggs and young larvae of certain species of Lepidoptera and less commonly on eggs and larvae of certain 


\section{Al-Keherb, Wafa, A.}

species of Coleoptera, and Diptera (Principi and Canard, 1984; New, 1984; and Miller et al., 2004). Some species of the aforementioned preys could be optimal for development and reproduction of $C$. Carnea, resulting in high larval developmental rates and increased preimaginal survival and adult longevity (Principi and Canard, 1984). The larvae of $C$. carnea considered as polyphagous, since they prey upon a great variety of aphid .Therefore, the development of larvae, pupae and adults may be affected by the prey hosts and temperatures. In the present study, it was noticed that the aphid species and temperature had a strong influence not only on preimaginal development of the predator but also on the female longevity and fecundity (Tables 1, 3 and Figures 1-4).

However, those prey species subserved rapid preimaginal development and high percentages of survival resulted in a better reproductive performance for $C$. carnea as well (Tables 2 and 4).

Moreover, the results clearly showed that nymphs of $A$. craccivora proved to be the most favourable for development and reproduction of $C$. carnea resulting in high immature survival rate, short larval developmental time and increased adult longevity and fecundity. The nymphs of $M$. persicae resulted in intermediate to low survival and reduced oviposition rates. Therefore, we cannot exclude the possibility that the highest suitability of $M$. persicae in relation to the other tested aphid species could be due to an adoption and/or preference that developed by the predator during the first generation, as it has also been reported for Chrysopa quadripunctata Burmeister (Albuquerque et al., 1994). However, similarly to our results a considerable variation has been found in the relative suitability of several aphid species when tested as prey for lacewing larvae. Great variation in developmental rate has been recorded for Chrysoperla species when fed on various aphid species (Principi and Canard, 1984). Development and reproduction of $C$. rufilabris (Burmeister) and C. carnea (Stephens) was favoured when fed on immature stages of M. persicae and Aphis gossypii Glover whereas Lipaphis erysimi (Kaltenbach) was of low nutritional value for both species (Chen and Liu, 2001). It could be also noticed that the total larval, pupal stages and adult longevity and life span of $C$. carnea at $250 \mathrm{C}$ showed non similar pattern at $30 \mathrm{oC}$ when fed on the two aphid species (Tables $1 \& 3$ ). This was in harmony with the results of Butler and Ritchie (1970) for C. carnea who noticed that the larval developmental time decreases with temperature elevation. Additionally, Cardoso and Lazzari (2003) showed that the development of $C$. externa (Hagen) was faster at $250 \mathrm{C}$ than lower temperatures used (20 and $15 \mathrm{oC}$ ).

Therefore, further experiments are required in order to clarify the suitability of different potential food sources and their combinations as well as the level of their availability on the predator's food preference and performance. 


\section{REFERENCES}

Albuquerque, G.S.; C.A. Tauber and M.J. Tauber (1994). Chrysoperla externa (Neuroptera: Chrysopidae): life history and potential for biological control in Central and South America, Biol. Control, 4: 8-13.

Butler, G. D. and P. L. Ritchie (1970). Development of Chrysopa carnea at constant and fluctuating temperatures. J. Econ. Entomol., 63: 10281030.

Cardoso, J. T. and S. M. N. Lazzari (2003). Development and consumption capacity of Chrysoperla externa (Hagen) (Neuroptera, Chrysopidae) fed with Cinara spp. (Hempitera, Aphididae) under three temperatures. Revista Bras. De Zool., 20 (4): 573-576.

Carvalho, F. P. (2006). Agriculture, pesticides, food security and food safety. Environ. Sci. \& Policy, 9 (7-8): 685-692.

Chen, T.Y. and T.X. Liu (2001). Relative consumption of three aphid species by the lacewing, Chrysoperla rufilabris, and effects on its development and survival, BioControl $46: 481-491$.

Corrales, N. and M. Campos (2004). Populations, longevity, mortality and fecundity of Chrysoperla carnea (Neuroptera: Chrysopidae) from oliveorchards with different agricultural management systems. Chemophere, 57: 1613-1619.

Costat software (1990).Microcomputer program analysis version 4.20,CoHort software, Berkeley. CA.

Daane, K.M. (2001). Ecological studies of released lacewings in crops. In: P.K. McEwen, T.R. New and A.E. Whittington, Editors, Lacewings in the Crop Environment, Cambridge University Press, Cambridge (2001), pp. 338-350

Damásio, J.; L. Guilhermino; A.M.V.M. Soares; M.C. Riva and C. Barata. (2007). Biochemical mechanisms of resistance in Daphnia magna exposed to the insecticide fenitrothion. Chemosphere, 70 (1): 74-82

Hydorn, S.B. and W.H. Whitcomb (1979). Effects of larval diets on Chrysopa rufilabris, Fla. Entomol., 62: 293-298.

Legaspi, J.C.; R.I. Carruthers and D.A. Nordlund (1994). Life history of Chrysoperla rufilabris (Neuroptera, Chrysopidae) provided sweetpotato whitefly Bemisia tabaci (Homoptera, Aleyrodidae) and other food, Biol. Control, 4: 178-184.

Mari, J. M.; I. A. Nizamani and M. U. Shar (2007). Predatory efficiency of Chrysoperla carnea (Stephens) on mustard and wheat aphid. Pak. J. Agri. Engg., Vet Sci., 23 (1): 28-30

Miller, G.L.; J.D. Oswald and D.R. Miller (2004). Lacewings and scale insects: a review of predator/prey associations between the Neuropterida and Coccoidea (Insecta: Neuroptera, Raphidioptera, Hemiptera). Ann. Entomol. Soc. Am., 97: 1103-1125.

Mochizuki, A. and T. Mitsunaga (2004). Non-target impact assessment of the introduced green lacewing Chrysoperla carnea (Stephens) (Neuroptera: Chrysopidae) on the indigenous sibling species, $C$. Nipponensis (Okamoto) through interspecific predation. Appl. Entomol. Zool., 39(2): 217-219. 


\section{Al-Keherb, Wafa, A.}

Nasreen, A.; G. Mustafa and M. Ashfaq (2003). Selectivity of some insecticides to Chrysoperla carnea (Stephens) (Neuroptera: Chrysopidae) in laboratory. Pak. J. Biol. Sci., 6(6): 536-538.

New, T.R. (1984). Chrysopidae: ecology on field crops. In: M. Canard, Y. Séméria and T.R. New, Editors, Biology of Chrysopidae, Dr. W. Junk Publishers, Boston, USA, pp. 160-167.

Principi, M.M. and M. Canard (1984). Feeding habits. In: M. Canard, Y. Séméria and T.R. New, Editors, Biology of Chrysopidae, Dr. W. Junk Publishers, Boston, USA: pp. 76-92.

Sattar, M.; M. Hamed and S. Nadeem (2007). Predatory potential of Chrysoperla carnea (Stephens) (Neuroptera: Chrysopidae) against cotton mealy bug. Pak. Entomol., 29(2): 103-106.

Sayed, A. N.; M. Ashfaq and S. Khan (2005). Comparison of development and predation of Chrysoperla carnea (Neuroptera: Chrysopidae) on different densities of two hosts (Bemisia tabaci, and Amrasca devastans). Pak. Entomol., 27(1): 41-44.

Tauber, M.J.; C.A. Tauber; K.M. Daane and K.S. Hagen (2000). Commercialization of predators: recent lessons from green lacewings (Neuroptera: Chrysopidae: Chrysoperla). Am. Entomol., 46 : 26-38.

Zia, K.; F. Hafeez; R. R. Khan; M. Rashed and U. Naeem-Ullah (2008). Effectiveness of Chrysoperla carnea (Stephens) (Neuroptera: Chrysopidae) on the population of Bemisia tabaci (Homoptera: aleyrodidae) in different cotton genotypes. J. Agric. \& Social Sci., 4 (3): 112-116.

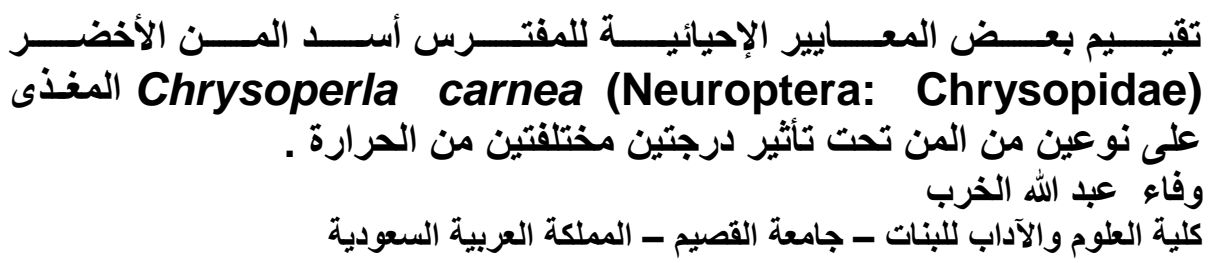

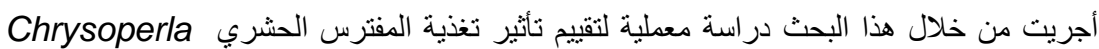
carnea

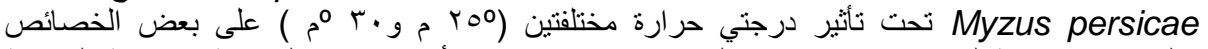
والمعايير الإحيائية لتقييم مدى كفاءة هذا المفترس عند استخدامه كأحد عناصر المكافحة الإحيائية الموجهة

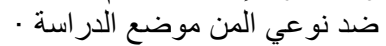
وقد أوضحت نتائج البحث عدم وجود فروق معنوية على المعايير الإحيائية لأسد المن الأخضر و التي لتئي

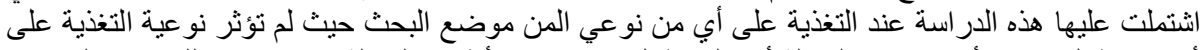

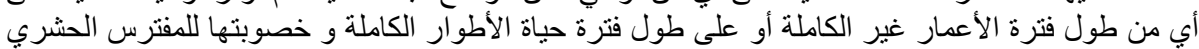

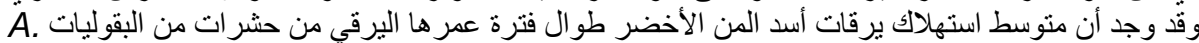
كان craccivora

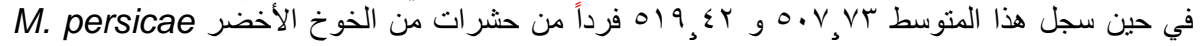

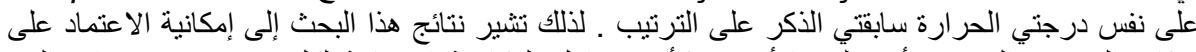
يرقات المفترس الحشري أسد المن الأخضر كأحد عوامل المكافحة الإحيائية لكل من نوعي حشرات الثرات المن موضع الدراسة الاستة الكلمات الافتتاحية : أسد المن الأخضر , المكافحة الإحيائية , من البقوليات , من الخوخ الأخضر . 